\title{
"Em ordem escrita as suas lembranças": performances da memória em Baú de ossos
}

\author{
Maria Alice Ribeiro Gabriel*
}

\begin{abstract}
Resumo
Recentemente, a crítica e a teoria literária têm especulado o tema da escrita. Este artigo expõe este tópico relacionando-o à temática da memória em Baú de ossos (1974), de acordo com as reflexões de Pedro Nava, Gilles Deleuze e Félix Guattari. O objetivo é discutir uma possível integração epistemológica entre o paradigma mnemônico apresentado pela escrita autobiográfica de Pedro Nava e o conceito filosófico de rizoma proposto por Deleuze e Guattari (1995). Com propósitos mnemônicos, o estilo criativo de Nava envolve um modelo de composição literária rizomático por natureza. A análise sugere que esse modelo ilumina tópicos relevantes para o estudo das Memórias.
\end{abstract}

Palavras-chave: Pedro Nava. Literatura. Memórias. Escrita criativa.

\section{Recollections in written order: performances of memory in Baú de ossos}

\begin{abstract}
In recent years, literary theory and criticism have speculated the subject of writing. This paper expose this subject related to the theme of memory in Baú de ossos (1974), according to reflexions of Pedro Nava, Gilles Deleuze and Félix Guattari. The objective is to discuss a possible epistemological integration between the mnemonic paradigm presented by Pedro Nava's autobiographical writing and the philosophical concept of rhizome proposed by Deleuze and Guattari (1995). For mnemonic purposes, Nava's creative style involves a model of literary composition which is rhizomatic in nature. The analysis suggests that this model illuminates relevant topics in the study of the Memoirs.
\end{abstract}

Keywords: Pedro Nava. Literatura. Memoirs. Creative writing.

Recebido: 06/01/2019

Aceito: 12/04/2019

* Universidade Federal de Uberlândia (UFU). Doutora em História Social pela Universidade de São Paulo USP. Pesquisadora vinculada ao Laboratório de Estudos Judaicos (LEJ). 
Nascido em 1903, Pedro da Silva Nava é um dos grandes autores da literatura brasileira. Para a memorialística nacional ele representa, sem dúvida, o nome mais significativo. Interrompido tragicamente em 1984, o projeto de suas Memórias é precedido de vários escritos sobre a Medicina, reunidos em Território de Epidauro, publicado em 1947, Capítulos da História da Medicina no Brasil e A Medicina de Os Lusíadas, publicados entre 2003 e 2004. O testemunho de Nava sobre o século XX, complementado por seu arquivo familiar - que inclui o acervo pessoal do escritor Antônio Salles - constitui valiosa fonte de pesquisa para a História cultural, a crítica e a historiografia literária. Como observador dos costumes, hábitos e tradições, sua obra registra, com riqueza de detalhes, o imaginário, vestuário, versos, relatos, misteres, gestos, farmacopeias, escritos privados, ditos populares, diários, canções, casos, anedotas, ambientes, todo um patrimônio material e imaterial que, sem o registro do autor, teria se dispersado e perdido no tempo, no "vácuo deixado pela alma que não mais atormenta" (NAVA, 1974, p. 78).

As Memórias recontam a vida privada e pública adotando modos diversos de narrar, do estilo novelesco ao do contador de histórias popular, criativo, envolvente e prosaico; do ensaísta refinado ao historiador sistemático. Estudioso da genealogia, história e literatura, fino observador da natureza humana, Nava retratou inúmeras personalidades, revelando perfis psicológicos inesquecíveis:

É curioso assinalar que entre todos os trastes, coisas, cacarecos, ferragens, móveis e roupas do inventário de Dona Dorotéia Augusta Filipina, não figura um só objeto religioso registro de santo, oratório, imagem, rosário de ouro... Voltando aos livros, uma palavra sobre o romance de Eugène Süe. Foi nele que o Halfeld ensinou francês à terceira mulher e a história calou tanto no seu espírito, que uma das filhas do seu matrimônio com meu avô chamou-se também Matilde. [...] Como os maus eram maus e os bons, como eram bons... e as elegâncias parisienses do romance e seus requintes sociais... O Rei, a Corte, os palácios, os castelos. Que tempo, que gente... Tempo em que Eugène Süe era mais conhecido e considerado maior escritor do que Balzac. E quem se lembra hoje de Matilde, de Le Juif Errant, de Les Mystères de Paris? e até do nome do autor desses rocamboles? (NAVA, 1974, p. 137).

Dentre muitos retratos, cabe ressaltar a passagem sobre o "eminente otorrinolaringologista" João Marinho de Azevedo (1875-1956), de quem Nava (1974, p. 374-375) foi paciente quando criança, "para o tratamento de garganta", ou melhor, de "abcessos periamigdalianos em era conservadora", "dois focos de infecção" periodicamente cauterizados com "estiletes em brasa fincados nas goelas": "O ar ficava impregnado de um cheiro de churrasco e de auto-da-fé. Meu Pai, cúmplice, conversava com o verdugo. Este era magro, alto, elegante, olhos claros e cabelos castanhos”, neto de médicos ilustres, como Domingos Marinho de Azevedo Americano e Manoel Joaquim de Valadão Pimentel, Barão de Petrópolis, catedrático e diretor da Faculdade de Medicina do Rio de Janeiro, "criador de nossa Medicina interna". Nava encontraria o médico anos mais tarde, em várias ocasiões, uma vez, "para obter informações sobre seu avô" materno, o Dr. Pimentel. Lamentando a oportunidade perdida, o possível memorialista, escrupuloso e elegante, “que podia ter sido e que não foi”, o autor comentou:

Guardei dessa minha visita a João Marinho a impressão do bom gosto com que ele reunira sua biblioteca de clássicos da Medicina e de clássicos portugueses, da prodigiosa memória de que ele era dotado e de sua capacidade de ditar em ordem escrita as suas lembranças. Ele não me deixava tomar notas do que dizia, com medo de falseamento da verdade e fez questão que eu escrevesse sob ditado. Terminado este e relidas as páginas de seu depoimento nada houve a corrigir no texto que lhe brotara simples, perfeito, completo e acabado. Eu sugeri, nessa ocasião, que João Marinho escrevesse suas memórias e, como ele falasse em falta de tempo, ponderei que um homem que criava verbalmente como ele o fazia - não precisava escrever. Era só ditar, o que tinha de dizer, ao microfone de um gravador. Nunca fez isto, creio. (NAVA, 1974, p. 375, grifo do autor). 
Fundada sobre anos de pesquisas, compreendendo fontes documentais escritas e não escritas, a prosa literária das Memórias mescla a História "oficial" e a história pessoal aos planos biográfico e autobiográfico. Esboçados com sensibilidade, mas sem eufemismos e complacência, alguns episódios da história familiar expõem figuras impressionantes, quase míticas, como aqueles protagonistas de grandes produções artísticas, capazes de eclipsar o nome do autor e da obra que os descreveu. Pedro Nava: mulheres reveladas e veladas (1999), de Ilma Salgado, e A mulher em Juiz de Fora sob o olhar de Pedro Nava (2015), de Rosali Henriques, resultam de pesquisas centradas nessas personalidades:

Tenho um daguerreotipo que representa minha avó e o seu irmão Júlio [...] em Sabará. Ele, com uma carinha neutra de menino emburrado, e ela, uma figura estranha, onde as mãos, os braços e o tronco de criança emergem duma saia balão. E esse conjunto é dominado não por uma face infantil, mas por uma cara adulta. Bonita cara, mas de expressão antipática e voluntariosa, com um olhar carregado de desconfiança e uma boca de dobra amarga. Analisando esse retrato e comparando-o com outros que Inhazinha tiraria mais tarde, veem-se os traços todos onde se delineariam primeiro as linhas do rosto da linda moça que ela foi; depois, as curvas da bela mulher madura; em seguida, as pelancas e as rugas da velha ainda pretensiosa, que eu conheci; os sulcos da ruína final que a arterioesclerose esculpia para a morte. Toda a evolução das personalidades que o tempo tira uma das outras, como aquelas mabouchkas russas em que se desatarraxa a primeira boneca para tirar dela a segunda; a segunda, para a terceira; a terceira, para a quarta; e depois a quinta, a sexta, a sétima - parecendo sempre a mesma, entretanto sendo outra, ${ }^{1}$ outra, outra, mais outra, mais fraca, mais fraca, até a última... (NAVA, 1974, p. 118).

O "negativo" de tais retratos sugere questões polêmicas sobre os limites éticos da escrita memorialística. Ao discutir o impacto da obra (auto)biográfica sobre o escritor e o grupo familiar que é, simultaneamente, personagem e leitor dessa criação, John D. Barbour (2004) prioriza as relações parentais, analisando como o autor elegeria determinados valores para representar o caráter moral de alguém. Pode ser árduo julgar quando quem escreve pondera sobre quais influências teriam moldado a personalidade de um parente - incluindo o fato de a pessoa descrita ter sido, em algum momento do tempo, uma criança reagindo a pressões familiares. Logo, se para o escritor “tout comprendre, c'est tout pardonner", 2 o projeto de contar uma vida torna mais difícil julgá-la - notavelmente, segundo Barbour (2004, p. 74), no caso do filho que relata a existência dos pais. Na passagem a seguir é possível notar como circunstâncias políticas do passado contestam ou reforçam a identidade do grupo familiar:

Juiz, desembargador, deputado provincial, deputado-geral, senador, ministro, conselheiro e Grande do Império, o Visconde de Jaguaribe era essencial e visceralmente uma pessoa de bem, um homem bom e um cavalheiro perfeito. Irradiava simpatia, como no derradeiro retrato que lhe ficou e a que minha imaginação dá colorido. [...] Inteligente também, político de valor, cidadão prestante. Não direi que fosse um gênio, mas também não concordo com a mediocridade que lhe atribuía Ennes de Souza. Má vontade de jacobino julgando figura de monarquista. E engraçado é que era a meu propósito que vinham essas opiniões desfavoráveis. Sempre que o menino saliente que eu era dava alguma opinião que parecia acima de sua idade, lá vinha o tio Ennes puxando a brasa para a sardinha de sua família. Meu filho, você herdou a inteligência de Pedro Nava... Ainda bem, ainda bem... Porque a gente do visconde, começando por ele, sempre teve serragem na cabeça... Não, tio Ennes,

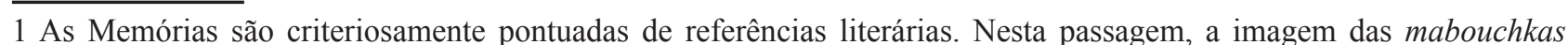
russas encontra seu correlativo em uma das sentenças de Dom Casmurro: "[...] se te lembras bem da Capitu menina, hás de reconhecer que uma estava dentro da outra, como a fruta dentro da casca" (ASSIS, 1978, p. 346 ). A mesma ideia é sugerida em um dos aforismos de João Guimarães Rosa (2009, p. 34), em “Antiperipléia: Caráter de mulher é caroços e cascas".

2 O perdão, afirmou Paul Ricoeur (2000, p. 626 ), é um tipo de reabilitação da memória, a consumação de um período de luto. Liberta do peso do débito, a memória é liberada para maiores projetos. O perdão oferece um futuro à memória. 
você só pensava em meu avô, em meu Pai. Você esquecia minha Mãe, uma das mulheres mais inteligentes que conheci. Se eu herdei, foi dos dois. (NAVA, 1974, p. 173, grifo do autor).

Em Baú de ossos, a exposição da imagem familiar entrelaça à história dos antepassados duas classes concêntricas de memória, uma local, doméstica, comunitária ou regional; outra mais ampla, relativa ao estado e ao país. Na primeira situação, a família personifica o domus e orienta o sentido de transmissão da herança moral que caracteriza o clã, garantindo-lhe reconhecimento no âmbito individual e coletivo. Nava define o perfil cultural da família paterna recuperando expressões, leituras, ocupações, vocabulário, um imenso contingente de traços particulares que manteriam o grupo unido:

Tenho visto noutros, mas jamais ultrapassada, aquela distinção moral e intelectual que eram as tônicas dentro do grupo familiar [...] e que davam à nossa gente (coincidentemente naquele tempo e naquele espaço) a consciência de um lugar certo, adequado e devido na sociedade da época. (NAVA, 1974, p. 350).

A memória familiar possui ainda uma relação com o espaço, constantemente mencionada por Nava:

Salvo um ou outro parente fixado em Pitangui e São João del Rei, a família de minha Mãe deitou raízes principalmente naquela zona que está para Minas e para o Brasil, como a Toscana para a Itália. Essa Etrúria nacional, sua parte mais alta (eu não falo só das montanhas!) e mais nobre (ah! solo imperial e patrício!) fica contida num círculo que passa seus arcos por Queluz, Bandeirantes, Cláudio Manoel, Fonseca, Bom Jesus do Amparo, União de Caeté, Lagoa Santa, Confins, Ribeirão das Neves, o meio das léguas entre Jatuaba e a Contagem, a Crucilândia, o Bituri e para fechar a rosca, outra vez Queluz... [...] Terras pesadas de espantos e metais. Noruegas cheias de avencas e assombrações. (NAVA, 1974, p. 103).

No modo peculiar como a família paterna assimilava e transmitia eventos marcantes da época, percebe-se que tipo de informação, literatura e valores eram considerados relevantes para a imprensa formadora de opinião durante a belle époque. A passagem a seguir exemplifica situações em que a memória familiar absorve o que acontece na sociedade, após um episódio dramático da história local, nacional ou mundial. E como gerações diferentes avaliam a repercussão de um evento traumatizante:

Era sempre nessa dependência - meio sala, meio escritório - que nossa família se reunia para conversar. A Marout gostava de evocar a história de Carleto, Roca e dos mancebos enganados. Foi meu primeiro folhetim de sangue... [...] Meu Pai, ao fazer a barba, costumava cantarolar o passo doble inspirado no caso. Sol-lá-si-dó-ré-dó-si... Mandei fazer um terno/ de jaquetão/ pra ver Carleto e Roca/ na Detenção... [...] Segundo folhetim - tim-tim por tim-tim. Mais sangue! A história de Euclides da Cunha contada por meu Pai. [...] Terceiro folhetim. Ainda sangue - Primavera de sangue... Quarto. Sangue real, de Portugal. Não d'El-Rei que vai à caça, mas d'El-Rei que foi caçado, no Terreiro do Paço. [...] Quinto folhetim. O sangue de Batista das Neves tingindo as águas da Guanabara. Mas isso era motivo de discussões entre meu Pai e tio Salles dum lado, favoráveis ao almirante negro e contra a chibata, e o futuro cunhado Heitor Modesto do outro, que, hermista e com velhos pruridos de disciplina, era pela cal virgem cortando os pulmões dos presos nos calabouços da Ilha das Cobras e pelos fuzilamentos em alto mar, como os levados a efeito a bordo do Satélite. Outra história de sangue, sexto folhetim, era a que contava tio Salles e que se dera em Fortaleza. Passou para a crônica da terra como o Três de Janeiro [...] Era a crônica das violências, das pancadarias, das mortes, dos exílios, das perseguições e das patotas que se desenrolavam no seu estado natal. Eu, de tanto ouvir falar em Accioly e nas maldades de Accioly, acabei dando dimensões sobre-humanas ao oligarca. Já não era mais um semelhante. No meu terror eu procedia a misturas e sincretismos, transportava-o para 
a legenda e fazia dele um ogre, monstro composto como as hidras ou troço entre o bicho e o homem, como as harpias. E morria de medo da avantesma criada pela minha própria imaginação. (NAVA, 1974, p. 375-348).

A maneira pela qual, a partir do vínculo estabelecido entre realidade e fantasia, a imaginação infantil passa a reconstruir, com o auxílio da memória, os eventos e figurantes da crônica familiar, é um tema explorado com humor e lirismo. As relações entre comunidades e indivíduos são valoradas seguindo a lógica do conto maravilhoso, filtrada pela memória coletiva e individual do narrador da cultura popular. "Além de ouvir a onda de poesias das histórias de Rosa eu as vivia porque alguns personagens de suas sagas andavam envultados em [pessoas] conhecidas de Juiz de Fora". Rosa era "cria da casa" da avó materna do escritor. Além de exímia contadora de histórias, "[...] sabia, ouvidas não sei onde nem de quem, todas as histórias de Andersen, Perrault e dos Irmãos Grimm”, cantava romances, como o de Juliana e Dom Jorge, e "[...] transformava o castelo peninsular consentâneo à tragédia, num sítio do Paraibuna e o cavaleiro Dom Jorge num peão matuto" (NAVA, 1974, p. 239-243). Assim, o "hirsuto" Dr. Henrique de Beauclair é descrito nessas passagens como um dos tipos legendários de médicos que Nava (1974, p. 241) havia conhecido na infância: "Gênio bom era o Doutor Beauclair. Diziam que era médico e era mesmo, por sinal que médico de meu irmão Paulo. Instruído pelas histórias da Rosa, eu sabia, apesar de sua estatura, que ele era um dos sete anões da Branca de Neve."

Nava atribui diversas funções à memória: afetar a maneira de contar histórias, selecionar as imagens de um fato que serão esquecidas e lembradas, iluminar ou obscurecer partes do passado. Nesse processo, esquecer é falha oportuna, recurso profilático e fator intrínseco à construção da memória. Emoção e imaginação complementam o trabalho do esquecimento. Mais que esquadrinhar o funcionamento da memória, Nava põe em perspectiva a forma como uma recordação é expressa.

Avaliar tais formas de expressão pressupõe a criação de uma hermenêutica da memória, na qual o esquecimento não é algo destrutivo, que produziria unicamente conflitos de interpretação ou distorções da verdade, mas é também recurso poético. Adotando essa hipótese, a proposta deste artigo é discutir duas temáticas de Baú de ossos (1972), a saber, a questão da memória autobiográfica e sua inclusão no sistema mnemônico esboçado por Nava. O objetivo é comparar esse sistema ao conceito de rizoma, modelo epistemológico idealizado pelos filósofos Gilles Delleuze e Félix Guattari (1980).

A intenção de comparação entre ambos os paradigmas se justifica por um aspecto que os torna similares: a permeabilidade que lhes permite comportar funções do intelecto, percepções e emoções, conciliando-as, por meio de múltiplas operações de associação, combinação, permuta ou supressão, a uma pluralidade de representações artísticas, culturais, literárias, oníricas, políticas e sociais. Assim, a noção de rizoma seria pertinente a um enfoque imagético, cinematográfico ou pictórico da memória, conforme o trecho em que Nava "recupera" a casa da infância através da recordação dos brinquedos:

Uma lanterna mágica com lâmpada de querosene, cujo cheiro ainda sinto, com o do seu verniz quente e o do seu metal candente. Nela se passavam vistas e um filme sem fim de extremos colados, com um desenho animado que me enchia de pânico pelo mistério da repetição, da retomada. [...] A mesma angústia que senti anos depois, no Museu do Prado, diante de três quadros em série, mostrando a história de Nastagio degli Honesti. [...] Segunda recordação - o caderno. [...] Presente de tio Salles que fora comprá-lo comigo [...] Pelo capricho da vida dos objetos, esse caderno ficou primeiro esquecido num caixote de livros de meu Pai. Quando ele reapareceu, fui aproveitando suas páginas em branco para novos desenhos que se superpuseram aos antigos como as camadas sucessivas de Tróia e onde só eu - Schliemann! - distingo o que é 1910, 1911, 1914 e 1918. [...] Esse caderno traz nas suas páginas o pó de uma longa sequência de casas cujo ambiente tornou-se dele inseparável. (NAVA, 1974, p. 353). 
Sob uma perspectiva autobiográfica, Nava diferencia, pela maturidade do intelecto, o arranjo ou funcionamento desse modelo mnemônico. A mente da criança conceberia "as camadas sucessivas" do tempo e do espaço como domínios confluentes. Para o menino que vivia entre a casa dos pais e a dos avós, esses locais formariam esferas intercomunicantes no cotidiano, muitas vezes, por exemplo, nos estados febris, representando zonas quase indiferenciadas, favoráveis ao devaneio, aos estados de consciência em que ilusão e realidade parecem amalgamados. No quadro referencial constituído pela memória infantil, esquecer é suprimir os intervalos de tempo encadeados em sucessão linear:

Não é bem como eu disse antes, que anoitecia aqui, para acordar ali. A memória é que suprimia os intervalos e permitia que eu passasse sem interrupção, da noite da Rua Direita aos terreiros ensolarados de secar café; da primavera da chácara do seu Carneiro ao verão do rio Comprido e aos frios do Paraibuna. $\mathrm{Na}$ vida ubíqua da infância, as perspectivas do tempo variavam como as do espaço e tudo ficava simultâneo, coexistente, como que superposto, entretanto transparente e visível - como os planos de uma radiografia que são n-planos - empilhados aos cem, aos mil, aos decimil e aos centimil da luminosidade de lâmina translúcida e una. (NAVA, 1974, p. 238).

A percepção do tempo, do passado, assim como a experiência de contar uma história, estaria impregnada de elementos simbólicos, tanto que Le Livre de Mon Ami, de Anatole France, concedeu a Nava a epígrafe inicial de Baú de ossos: "Ainsi, il me paraît, en ce moment, que la memóire est une faculté merveilleuse et que le don de faire apparaître le passé est aussi et bien meilleur que le don de voir l'avenir." "A diversidade de manifestações que uma recordação pode assumir na criação literária é o ponto de partida para especulações da memorialística e suas expressões afins no plano da ficção.

Leitor culto, Nava busca responder tais indagações conjugando recursos de análise próprios aos métodos investigativos de disciplinas, como a arqueologia, a historiografia, a história da arte, a medicina e a sociologia. "Associação", "curso de pensamento", "encadeamento regido pelo hábito", "fantasma", "lembrança”, "ilogismo onírico", "memória” e "recordação" são termos que preenchem as divagações do escritor bissexto sobre os possíveis caminhos da mente para lembrar e esquecer.

A memória é "sistema de recuperação do tempo", do "jamais". A "percepção desse processo de utilização da lembrança" direciona o escritor para a "retomada" do passado. Porém, as "chaves da memória" são voláteis e seu advento "tem algo da violência e subitaneidade de uma explosão", que pode ser acionada por crenças, ritos, saberes, sensações, símbolos, sonhos e atos fortuitos, “[...] dentro da rotina dos acontecimentos tristes ou alegres que são a história da vida e a história de todo mundo" (NAVA, 1974, p. 190). As "chaves da memória" incluem-se ainda na questão da transmissão cultural ao longo do tempo, devido à sua importância na construção da identidade e do imaginário coletivos:

A memória dos que envelhecem (e que transmite aos filhos, aos sobrinhos, aos netos, a lembrança dos pequenos fatos que tecem a vida de cada indivíduo e do grupo com que ele estabelece contatos, correlações, aproximações, antagonismos, afeições, repulsas e ódios) é o elemento básico na construção da tradição familiar. Esse folclore jorra e vai vivendo do contato do moço com o velho - porque só esse sabe que existiu em determinada ocasião o indivíduo cujo conhecimento pessoal não valia nada, mas cuja evocação é uma esmagadora oportunidade poética. Só o velho sabe daquele vizinho de sua avó, há muito coisa mineral dos cemitérios, sem lembrança nos outros e sem rastro na terra - mas que ele pode suscitar de repente (como o mágico que abre a caixa dos mistérios) na cor dos bigodes, no corte do paletó, na morrinha do fumo, no ranger das botinas de elástico, no andar, no jeito - para o menino que está escutando e vai prolongar por mais cinquenta, mais sessenta anos a lembrança que lhe chega, não como coisa morta, mas viva qual flor olorosa e colorida, límpida e nítida e flagrante como um fato presente. E com o evocado vem o mistério das associações trazendo a rua, as casas antigas, outros jardins, outros homens, fatos pretéritos,

3 Em uma tradução livre: “Assim, parece-me, nesse momento, que a memória é uma faculdade maravilhosa e que o dom de fazer ressurgir o passado sobrepuja o dom de vislumbrar o porvir." 
toda a camada da vida de que o vizinho era parte inseparável e que também renasce quando ele revive - porque um e outro são condições recíprocas. (NAVA, 1974, p. 17).

O excerto alusivo ao retrato do avô homônimo, Pedro da Silva Nava (1843-1880), seria uma tentativa de reconstituir a "viagem" que memória, imaginação e percepção sensorial empreendem juntas, partindo do "evocado" para percorrer o mar "do Tempo" e do "mistério das associações":

É por ser neto do retrato que sou periodicamente atuado pela necessidade de ir a São Luís do Maranhão. Essa sempre procrastinada viagem, se não a faço com o corpo, realizo em imaginação. Desde menino, quando, de tanto ouvir falar em Ceará e Maranhão, eu enchia cadernos e cadernos de desenho de navios inverossímeis, onde havia um exagero de âncoras pendentes, gáveas em cada metro de mastro, mastros sem conta e as chaminés deitando uma fumaceira de erupção vulcânica. Nenhum barco da minha frota tinha menos de seis dessas chaminés e, além delas, velas, rodas e hélices para os grandes mares e os grandes ventos. É sempre na mezena mais alta de um deles que levanto minha flâmula e orço para o setentrião - quando certos sons, certas sílabas e certos nomes mágicos abrem para mim os caminhos do oceano. Ilha, rei, São Luís Rei. Ou então, mar, amar, aranha, arranhão que se entrelaçam e emaranham na graça da palavra Maranhão. E mais a sombra de Sinhá Graça que, menino, eu vi passar toda de negro. E ainda, Heráclito Graça, Graça Aranha... [...] Estranha e perturbadora São Luís... A ela me levavam também outras associações mais perigosas [...] a me sugerir o Maranhão. Um Maranhão menos confessável. (NAVA, 1974, p. 21-23).

A "oportunidade poética" surgiria apenas "quando certos sons, certas sílabas e certos nomes mágicos abrem [...] os caminhos do oceano" das "associações", da percepção sensorial e do onirismo ou estaria ligada ao aprimoramento do que o próprio memorialista chama de "emoção estética"? Nava usa alguns métodos para "recuperar o morto", ou seja descrever a personalidade de um ente falecido. A identificação de características do ambiente, caráter, fisionomia ou história dessa pessoa com obras de arte é um desses métodos, que muitas vezes inclui a ideia de "transmissão". Por exemplo, a recordação de infầncia do poeta Dilermando Martins da Costa Cruz, "dono do sorriso mais contagioso que se possa imaginar". Nava refere ter conservado das visitas à casa dessa gentil família que ele "adorava",

[...] uma impressão veludosa e colorida. Vastos claros de paredes brancas, pardos de mobílias lustrosas, verde musgo de cortinas e panos de mesa, compondo natureza-morta onde as cores eram surdas e sem estridência, como nos quadros de Bracque. Essa impressão é absolutamente real e eu a descobri porque, vendo álbuns com reprodução de suas telas ou as que estão no Palais d'Art Moderne, de Paris, acudia-me sempre a lembrança do Dr. Dilermando Cruz. Quando isto aconteceu pela quinta, sexta, sétima vez, vi que essa associação não podia ser causalidade da mente errante e que havia uma motivação para ela. Estudei sua lembrança, a de seus filhos, a de sua esposa e afinal a de sua residência. Era esta que me levava a liga-lo a Georges Bracque [...] por suas salas cuja arrumação e cujas tintas me prepararam para entender as guitarras, violinos, facas, jarros e travessas de beleza mitológica e de cor abafada do pintor fauvista e cubista. (NAVA, 1974, p. 279-280).

"Muito mais tarde", Nava teria apenas um "encontro rápido" com dois filhos de Dilermando Cruz, "o bastante para recuperar, em ambos, a mesma simpatia e o mesmo sorriso do pai". Já O nascimento de Vênus (1486) é chave que permite a Nava (1974, p. 31) recuperar a beleza da avó paterna: "Linda de pele, de dentes, de cabelos, de corpo e do airoso porte. Linda - do pescoço serpentino como o da Simonetta Vespucia do quadro de Sandro Botticelli." Os "enormes olhos verdes" da avó, Dona Ana Cândida Pamplona da Silva Nava, por meio da ideia de transmissão, também são "chaves", pois repetem um padrão que identifica um grupo de indivíduos e indicam os traços "cheios de sugestões" envolvidos na constelação de imagens poeticamente ativadas pelo trabalho da memória associativa: 
Os extraordinários olhos dos Pamplonas que, esmeraldinos como os dela, ou azuis, ou castanhos ou pretos, são sempre os mesmos - doces, rasgados, cheios de sugestões das coisas curvas e infinitas, lembrando a placidez das noites de lua e a distâncias de calmos mares. Esses olhos - de antropológica qualidade céltica, ibérica e lusíada, vieram da península com certo Hipólito Cassiano Pamplona. De geração em geração chegaram a seus bisnetos - minha avó e seus irmãos e são os mesmos dos retratos dos primos de meu Pai. (NAVA, 1974, p. 31).

Não só o cinema, a fotografia, a pintura e a herança genética, corroboradas por fontes documentais e testemunhos, investem o campo da memória para restituir ao presente cenas do passado. $\mathrm{Na}$ mente da criança, emoções, expectativas, fantasias e medos imaginários deturpam, estimulam e mesclam lembranças a imagens que, para o adulto, são consideradas ilusórias, a exemplo da figura do Comendador Antônio Pinto Nogueira Accioly, misto de "avantesma" e "ogre" ou a do médico que o pequeno Nava (1974, p. 250) acreditava personagem de conto de fadas, o "[...] Dr. Beauclair que estava sempre na janela. Por sua porta eu procurava o ataúde de cristal de Branca de Neve". Recuperar a presença do avô Pedro da Silva Nava parece exigir da "memória associativa" do adulto trabalho análogo ao dessa memória infantil, habilidosa em confeccionar fatos, informes e impressões:

Sua bondade, sua afetividade, sua doçura, testemunhada por todos que o conheceram, transparece na sua correspondência e fê-lo inesquecível dos filhos que mal o viram, mas em que ele deixou aquela impregnação meio táctil, meio olfativa, meio vígil, meio onírica com que as crianças (antes da memória associativa) reúnem o material para a construção do fantasma favorável, da sombra propícia. Avejão paterno, espectro materno - que os envultam, neles encostam e por eles passam a atuar como se estivessem vivos. (NAVA, 1974, p. 26, grifo do autor).

A trama efetuada através da memória associativa, "sistema de evocação", é comparada a um "processo mental" cuja "mecânica lancinante" teria sido desvendada por Marcel Proust. Se o percurso que essa "mecânica" efetua possui uma orientação retroativa, seu produto final estaria concatenado a uma lembrança futura, observável no conjunto resultante da soma de emoções e imagens originadas de eventos ulteriores. Em As estórias de Tutameia (1968), o crítico Paulo Rónai observou que,

[...] na própria contextura de certos contos o inexistente entremostra a vontade de se materializar. Em conversa ociosa, três vaqueiros inventam um boi cuja ideia há de lhes sobreviver consolidada em mito incipiente ("Os três homens e o boi"). Alguém, agarrado a um fragmento de frase que lhe sobrenada na memória, tenta ressuscitar a mocidade esquecida ("Lá, nas campinas"). Ameaça demoníaca de longe, um touro furioso se revela, visto de perto um marruás manso ("Hiato"). Noutras peças, o que não é passa a influir efetivamente no que é, a moldá-lo, a mudar-lhe a feição. O amante obstinado de uma megera, ao morrer, transmite por um instante aos demais a enganosa imagem que dela formara ("Reminisção"). (RÓNAI, 2009, p. 22).

No conto "Desenredo" (1967), de João Guimarães Rosa, o protagonista ilustraria essa função didática ou reparadora da memória. $\mathrm{O}$ desejo do intangível passa a tecer a constituição do futuro, as cenas do passado são restituídas à memória com feição nova, em que se inscrevem realidade e ilusão:

No decorrer e comenos, Jó Joaquim entrou sensível a aplicar-se, a progressivo, jeitoso afã. [...] Entregou-se a remir, redimir a mulher, à conta inteira. Incrível? [...] Disse-se e dizia isso Jó Joaquim. Reportava a lenda a embustes, falsas lérias escabrosas. Cumprialhe descaluniá-la, obrigava-se por tudo. Trouxe à boca-de-cena do mundo, de caso raso, o que fora tão claro como água suja. Demonstrando-o, amatemático, contrário ao público pensamento e à lógica, desde que Aristóteles a fundou. [...] Sem malícia, com paciência, sem insistência, principalmente. O ponto está em que o soube, de tal arte: por antipesquisas, acronologia miúda, conversinhas escudadas, remendados testemunhos. Jó Joaquim, genial, 
operava o passado - plástico e contraditório rascunho. Criava nova, transformada realidade, mais alta. Mais certa? (ROSA, 2009, p. 53).

Que papéis a realidade e a imaginação desempenham junto à memória para "abrir os batentes do maravilhoso"? Abordar esse mecanismo seguindo a influência de Proust subentenderia desvendar as relações de pertinência entre a memória e os sentidos. O campo da neurofisiologia da memória tem investigado como a percepção sensorial pode recuperar, mas igualmente, deformar e reconstituir fatos do passado, criando escritos, expressões artísticas, relatos e testemunhos que unem realidade e ficção. Nesta passagem, o paladar seria co-criador da memória e de uma "transformada realidade, mais alta":

Se a batida do Ceará é uma rapadura diferente, a batida de minha avó Nanoca é para mim coisa à parte e funciona no meu sistema de paladar e evocação, talqualmente a madeleine da tante Leonie. Cheiro de mato, ar de chuva, ranger de porta, farfalhar de galhos ao vento noturno, chiar de resina na lenha dos fogões, gosto dágua de moringa nova - todos têm a sua madeleine. Só que ninguém a tinha explicado como Proust - desarmado implacavelmente, peça por peça, a mecânica lancinante desse processo mental. Posso comer qualquer doce, na simplicidade do ato e de espírito imóvel. A batida, não. A batida é viagem no tempo. [...] Para mim, roçar os dentes num pedaço de batida é como esfregar a lâmpada de Aladim - abrir os batentes do maravilhoso. [...] Docemente mastigo, enquanto uma longa fila de sombras vem dos cemitérios para tomar o seu lugar ao sol das ruas e à sombra das salas amigas ... A vida recomeça como a projeção (no vácuo) de um filme de cinema mudo. (NAVA, 1974, p. 35).

“Tudo, para mim, é viagem de volta", afirma o protagonista de "Antiperipléia" (ROSA, 2009, p. 31). O tema da "viagem no tempo", da "recherche du temps perdu", põe em causa, além da noção de memória associativa e dos métodos do memorialista, a questão da subjetividade, do "instinto":

Para recompor os quadros de minha família paterna tenho o que ouvi de minha avó, de meus tios-avós Itríclio e Marout, das irmãs de meu Pai, de algumas primas mais velhas. Uns retratos. Umas folhas de receituário de meu primo Carlos Feijó da Costa Ribeiro com genealogias registradas por ele. Cartas. Cadernos de datas de meu avô Pedro da Silva Nava e de meu tio Antônio Salles. Notas diárias da mulher deste, Alice. Daí tenho de partir como Cuvier do dente e o ceramista do caco. No mais, há que ter confiança no instinto profundo de minha alma, de minha carne, do meu coração - que rejeitam como coisa estranha o que sentem que não é verdade ou que não pode ser verdade. Há também os objetos [...] (NAVA, 1974, p. 41).

O problema da "verdade" ou "do que não pode ser verdade" é assunto controverso para os pesquisadores da memória. ${ }^{4}$ A questão da veracidade de um relato está implícita no discurso de alguns protagonistas de Rosa (2009, p. 34): "Voltar, para fim de ida. Repenso, não penso. Dou de xingar o meu falecido, quando as saudades me dão". Para Nava (1974, p. 43), a memória ofereceria mais de um caminho para as ações de recriar e recordar: "Não preciso recriar o sobrado de Joaquim Feijó de Melo porque este eu conheci. Basta recordar. Nele entrei pela primeira vez em 1905, com pouco mais de dois anos, quando fui ao Ceará para me batizar”. Em fevereiro de 1919, Nava retorna ao Ceará para conhecer melhor a avó paterna, duas vezes viúva: a primeira, de Pedro da Silva Nava, morto em maio de 1880, aos trinta e cinco anos, a segunda, de Joaquim Feijó de Melo, falecido a 21 de outubro de 1917. Neste trecho, recordar e recriar são operações combinadas, mediadas por estímulos, imagens e impressões:

4 A chamada "Ciência da falsa memória" obteve repercussão mundial com os estudos polêmicos de Elizabeth Loftus, em parte, por suas implicações na psicologia forense. Em complemento a esses estudos, no campo da filosofia, cabe ressaltar The Wake of the Imagination (1998), Poetics of Imagining (1998), "Narrative and the Ethics of Remembrance" (1999) e The Politics of Memory: Between History and Imagination (2014), que expõem o pensamento de Richard Kearney sobre as "éticas da memória" e como esta delibera entre os campos do conhecimento, emoção, fantasia, linguagem e realidade. 
O térreo, revestido de ladrilhos hexagonais em cerâmica vermelha e esse chão era todo desigual de nível (velha casa construída sobre areias), de modo que ao andar tinha-se uma sensação de solo impreciso onde aqui e ali falhava o pé. Anos depois tive a mesma insegurança em Veneza, caminhando no pavimento de São Marcos - que parece movediço, como se prolongasse a ondulação da laguna. Tive aí estranha impressão. Olhava os mosaicos da cúpula e as figuras da "Ascensão" me faziam pensar em Dona Nanoca. A "História de São Marcos", a "Glória do Paraíso", "O Julgamento Final", e lembrava o Ceará. A "Pala d'Oro"; e ocorria-me a reverberação das areias do Mucuripe. Parado, eu estava em Veneza. Se começava a andar, sentia-me em Fortaleza. Subitamente percebi o que suscitava a associação de ideias bizarra e dissonante. O chão. Era o chão de São Marcos que obrigava a posições que me transmitiam aos ossos e tendões atitudes especiais de equilíbrio que eu tinha executado pela primeira vez na Rua Formosa 86 e que me passavam da medula às camadas conscientes do cérebro, devolvendo-me as primeiras comparações de um piso aqui elevado, ali deprimido - como superfície de águas ondulando à brisa que subitamente se petrificasse. (NAVA, 1974, p. 44).

Para a segunda parte do IV capítulo de Baú de ossos, Nava escolheu por epígrafes passagens de Machado de Assis e Proust ${ }^{5}$ sobre o tema da memória na composição da obra literária. A primeira citação ${ }^{6}$ envolve os capítulos LIX e LX de Dom Casmurro, intitulados, respectivamente, "Convivas de boa memória" e "Querido opúsculo". Capítulos em que a narrativa é permeada pelo tom ensaístico, com passagens digressivas, filosóficas e metalinguísticas. Nas "reminiscências", a "pena" "emenda" o que "pode ser olvido e confusão" nos "livros confusos" e nos livros "omissos", mas cabe às "ideias finas" e "reflexões profundas" preencher as "lacunas" da cena cujo registro não existe ou se perdeu:

Há dessas reminiscências que não descansam antes que a pena ou a língua as publique. Um antigo dizia arrenegar de conviva que tem boa memória. A vida é cheia de tais convivas, e eu sou acaso um deles, conquanto a prova de ter a memória fraca seja exatamente não me acudir agora o nome de tal antigo; mas era um antigo, e basta. Não, não, a minha memória não é boa. Ao contrário, é comparável a alguém que tivesse vivido por hospedarias, sem guardar delas nem caras nem nomes, e somente raras circunstâncias. A quem passe a vida na mesma casa de família, com os seus eternos móveis e costumes, pessoas e afeições, é que se lhe grava tudo pela continuidade e repetição. Como eu invejo os que não esqueceram a cor das primeiras calças que vestiram! Eu não atino com a das que enfiei ontem. Juro só que não eram amarelas porque execro essa cor; mas isso mesmo pode ser olvido e confusão. E antes seja olvido que confusão; explico-me. Nada se emenda bem nos livros confusos, mas tudo se pode meter nos livros omissos. Eu, quando leio algum desta outra casta, não me aflijo nunca. O que faço, em chegando ao fim, é cerrar os olhos e evocar todas as cousas que não achei nele. Quantas ideias finas me acodem então! Que de reflexões profundas! Os rios, as montanhas, as igrejas que não vi nas folhas lidas, todos me aparecem agora com as suas águas, as suas árvores, os seus altares, e os generais sacam das espadas que tinham ficado na bainha, e os clarins soltam as notas que dormiam no metal, e tudo marcha com uma alma imprevista que tudo se acha fora de um livro falho, leitor amigo. Assim preencho as lacunas alheias; assim podes também preencher as minhas. (ASSIS, 1978, p. 254).

5 Un des chefs-d'ouvre de la littérature française, Sylvie, de Gérard de Nerval, a tout comme le livre des Mémoires d'Outre Tombe, relatif à Comburg, une sensation du même genre que le goût de la madeleine et "le gazouillement de la grive". Chez Baudelaire, enfin, ces réminiscences plus nombreuses encore, sont évidemment moins fortuites et par conséquent à mon avis décisives. C'est le poète lui-même qui, avec plus de choix et de paresse, recherches volontairement, dans l'odeur d'une femme par exemple, de as chevelure et de son sein, les analogies inspiratrices que lui évoqueront "l'azur du ciel immense et rond" et "un port rempli de flammes et de mâts". J'allais chercher à me rappeler les pièces de Baudelaire à la base desquelles se trouve ainsi une sensation transposée, pour achever de me replacer dans une filiation aussi noble... (PROUST apud NAVA, 1974, p. 303).

6 "Vês que não pus nada, nem ponho. Já agora creio que não basta que os pregões de rua, como os opúsculos de seminário, encerrem casos, pessoas e sensações; é preciso que a gente os tenha conhecido e padecido no tempo, sem o que tudo é calado e incolor" (ASSIS, 1978, p. 255). 
Caberia à imaginação nostálgica e poética do escritor "cerrar os olhos e evocar todas as coisas" ausentes de um livro ou da lembrança, recuperada em livro de memórias por Nava (1974, p. 365): "Fecho os olhos, hoje. Evoco Aristides Lobo e seu sobrado morto e demolido". Quando caminha pelas "[...] ruas do Rio de Janeiro que parecem ser as mesmas e que entretanto passaram pela caixa do mágico e sua transformação impalpável", em busca do sobrado da Rua Aristides Lobo, n ${ }^{\text {106, }}$ Nava lembra o artífice que emprega métodos do arqueólogo e do restaurador de obras de arte: "Custei a recuperá-lo. Aviltado pelos anos e reformas sucessivas, recoberto de uma camada de cimento fosforescente e pó de mica, que tinha substituído o velho revestimento e o ultramar da pintura da fachada - não havia meios da recordação provocada entregar-me a velha imagem" (NAVA, 1974, p. 301). Assim, Baú de ossos apresenta descrições acuradas das fontes documentais ao alcance do memorialista. Nesta passagem, o "interesse pela pintura" e história familiar remonta a 1919, quando ele contava 16 anos:

Essa tela de Nossa Senhora com o Menino (barbaramente restaurada por nossa prima Cotinha Belchior) pertenceu a minha avó que explicou, vendo meu interesse pela pintura: "Essa é Nossa Senhora da Divina Providência, Foi de minha tia Loló. Está na família há bem trezentos anos..." Um quadro conservado três séculos e o fato de se saber disto, depois das nove gerações comportadas por esse prazo, mostram uma estabilidade de posição social (mesmo modesta!), um espírito tradicionalista, um respeito pelo passado e pelo antepassado que podem ser atestados, jurados e historiados. Sobretudo porque eu vi a contraprova dessas categorias na polidez, na cerimônia, no decoro, na reserva, no apuro e na decantação da elegância moral de minha gente paterna. (NAVA, 1974, p. 42).

Nava é um "conviva de boa memória" e cuidadoso ao reconstituí-la. Algumas lembranças da infância datam de 1905, como a visita a casa dos avós paternos, no Ceará, por ocasião de seu batismo:

Não tenho dessa viagem senão a vaga recordação da forma de uma escotilha - redonda e duramente luminosa, feito lâmpada cialítica - e, do lado de fora, alguma coisa oscilando como ponteiro dum metrônomo, ponta de madeira e pano, decerto mastro de falua encostado em navio atracado (NAVA, 1974, p. 43).

Há lembranças da eleição que levou o médico Duarte de Abreu (1859-1928) à presidência da Câmara Municipal de Juiz de Fora: "Isto foi 1905, eu tinha dois anos e é espantoso que a cena tivesse sido guardada por minha memória. Mas foi” (NAVA, 1974, p. 237). A cena evoca outras recordações ligadas a seu pai, José Pedro da Silva Nava: "Vi-o num dia limpar seu revólver, enferrujado [..] prometendo hecatombes a minha mãe consternada. Naquele dia eu ouvi pela primeira vez a palavra “eleição"'NAVA, 1974, . No entanto, em vez de usar a arma, o jovem clínico iluminou as sacadas do sobrado familiar, “à Rua Direita 142”, “com lanternas japonesas para ver desfilarem os estudantes do Granbery ${ }^{7}$ urrando entusiasmados" versos de improviso, "[...] com rimas às vezes certas e às vezes erradas como quando se perguntava pelos políticos serenos e sutis. Qual o político mais fino/ É o Constantino! / Qual o político mais calmo? É o Doutor Nava!" As recordações do filho que vê o "[...] Pai entregar-se a seus misteres formidolosos e domésticos" (NAVA, 1974, p. 236) compreendem o mecanismo associativo da memória sensorial de longo prazo:"Outra lembrança que tenho de meu Pai, à Rua Direita 142, é a da sua figura cuidando da plantação de estramônio. [...] O cheiro forte, tenaz e enjoativo impregnou minhas narinas e reside em mim com outros relentos de farmácia que encheram minha infância” (NAVA, 1974, p. 237). A percepção sensorial constituiria assim a função de um gatilho para “o milagre da memória involuntária”, referido por Nava (1974, p. 301).

7 A instituição de ensino Juiz de Fora High Scholl and Seminary foi fundada pelo missionário J. M. Lander em 1899 e mais tarde denominada Collegio Americano Granbery, em deferência ao bispo metodista John Cowper Granbery. Para o eleitor republicano juiz forense: "O ambiente educacional instalado abria espaço através dos grêmios literários e de jornal com redação a cargo dos discentes. Isso tudo, mais um estilo de educação baseado na máxima "pensar e ser livre para pensar", conduziria o alunado a um elevado nível de conscientização política”, segundo Firmino de Netto (1997, p. 223). 
Porém há vários fatores desencadeantes dessa memória. Lembrar e esquecer são processos de ordem fisiológica e psíquica. Intelecto e vontade apenas não determinam a acuidade das recordações, embora a mnemônica escolástica buscasse desenvolvê-la. Nesta acepção, perscrutar e depurar o ato de lembrar é exercício constante para Nava (1974, p. 287): “Eu tinha seis para sete anos, mas nascera com o dom de observar e guardar", distinguindo-o do narrador machadiano, que recorda "somente raras circunstâncias" e inveja "os que não esqueceram a cor das primeiras calças que vestiram!" (ASSIS, 1978, p. 254).

Ao considerar os meios pelos quais se percebe um objeto, Brian MacWhinney (2005, p. 200) ofereceu vislumbres sobre o funcionamento da memória sensorial. Por exemplo, ao ver uma fruta, não se receberia nada mais que uma imagem, com forma e cor. Entretanto, a interação imediata com a fruta gera percepções e sensações adicionais, permitindo discernir aroma, peso, sabor e textura. Todas essas interações envolvendo visão, olfato, tato, cinestesia, propriocepção e feedback locomotor provêm de um único objeto, categorizado como fruta. Essa gama diversa e rica de sensações e planos motores formaria o arcabouço concernente ao entendimento da palavra que designa aquela fruta, mas existem elementos, como fatos declarativos sobre a fruta, que não derivam dessa percepção direta.

A percepção direta pode ser revisada e redirecionada por dissociação por meio da "imageria" mental, assim como a experiência direta também seria "capturada" e reproduzida por um sistema de imageria mental. Para MacWhinney (2005, p. 201), ao se imaginar uma maçã, imagens de seu aroma, forma e sabor são evocadas, sem o fruto estar presente. A imageria conecta-se a funções cognitivas em áreas cerebrais ligadas à capacidade de planejamento, direcionamento de perspectiva, sonhos e memória. Nava concebe o mecanismo de funcionamento da memória tendo por referência o modelo proustiano de "recuperação do tempo" "irresgatável e incorruptível". Esse sistema é ativado por uma percepção-chave específica que, uma vez atuante, estabelece conexões em rede em torno de uma "lembrança":

Então é isto... Nela eu entro, na velha casa, como nela entrava nos jamais. Esse portão de ferro prateado eu o abro com as mesmas chaves da memória que serviram ao nosso Machado, a Gérard de Nerval, a Chateaubriand, a Baudelaire, a Proust. Todo mundo tem sua Madeleine, num cheiro, num gosto, numa cor, numa releitura - na minha vidraça iluminada de repente! - e cada um foi um pouco furtado pelo petit Marcel porque ele é quem deu forma poética decisiva e lancinante a esse sistema de recuperação do tempo. Essa retomada, a percepção desse processo de utilização da lembrança (até então inerte como a Bela Adormecida no Bosque do inconsciente) tem algo da violência e da subitaneidade de uma explosão, mas é justamente o seu contrário, porque concentra por precipitação e suscita crioscopicamente o passado diluído - doravante irresgatável e incorruptível. Cheiro de moringa nova, gosto de sua água, apito de fábrica cortando as madrugadas irremediáveis. ${ }^{8}$ (NAVA, 1974, p. 303).

Unindo o plausível ao poético, o sentido do olfato ocupa posição de destaque na imageria que pervade a reconstituição do trajeto percorrido pelo avô Pedro da Silva Nava, de seu sobrado, na Rua Ipiranga 61, para trabalhar em sua casa comissária, na Rua General Câmara 74, entre 1879 e 1880 :

Não é difícil imaginar como ele faria esse caminho se juntarmos à verdade o verossímil que não é senão um esqueleto de verdade encarnado pela poesia. [...] Vestido de sobrecasaca o ano todo [...] respirando o cheiro especial do velho centro do Rio de Janeiro - misto de exalações de frutas frescas e frutas podres, da bosta dos estábulos, dos moinhos de café, das barracas de peixe, dos montes de lixo, de leite azedo, de queijo ardido, dos mercados

8 No início de agosto de 1911, logo após o falecimento de José Pedro da Silva Nava, em 30 de julho, D. Diva Mariana, grávida do quinto filho, decide voltar para a casa de D. Maria Luísa, em Juiz de Fora. Entre as "madrugadas irremediáveis" estaria a que encerra a partida da viúva do Rio de Janeiro: “À hora de levantar, ainda escuro, ouvimos pela última vez o apito da fábrica e ao seu silvo lancinante minha Mãe começou a chorar - entendendo pela primeira vez aquele apelo prolongado que a chamava para sua vida de operária dos filhos, de proletária da família” (NAVA, 1974, p. 391). 
de flores, do perfume das senhoras que passavam rangendo sedas - machadianas Fidélias, Capitolinas e Virgílias! E do bodum da pretalhada carregando fardos [...] No meio desse fervilhar de vida passava meu avô para chegar à sua Rua de Gonçalo Gonçalves. Caminho de Gonçalo Gonçalves. Eis o primeiro nome que teve a Rua General Câmara. (NAVA, 1974, p. 67-70).

A passagem biográfica ajusta-se ao comentário de Proust n'O Tempo Reencontrado, sobre o aspecto mais decisivo que fortuito das reminiscências na obra de Baudelaire e de como "l'odeur d'une femme" suscitaria analogias e inspirações de imagens ao poeta. Nava (1974, p. 303) utiliza esse argumento para complementar a tese exposta em Dom Casmurro, que vincula ao ofício do escritor a combinação ideal entre experiência, imaginação e memória. Para descrever adequadamente uma reminiscência, é preciso ter "conhecido e padecido no tempo" os "casos, pessoas e sensações" encerrados nos "pregões de rua" e "opúsculos de seminário". A partir de correspondances que abrangem diferentes planos sensoriais, Nava elabora uma teoria memorialística do esquecimento, tornado "capítulo da memória":

É impossível dar uma impressão cronológica dessa fase de minha infância. Só de uma ou outra coisa ocorrida com gente grande e de que ficou memória em velhos documentos, em cartas onde a tinta se apaga. Do que eu vi, nada posso encadear [...] É impossível colocar em série exata os fatos da infância porque há aqueles que já acontecem permanentes, que vêm para ficar e doer, que nunca mais são esquecidos, que são sempre trazidos tempo afora, como se fossem dagora. É a carga. Há os outros, miúdos fatos, incolores e quase sem som - que mal se deram, a memória os atira nos abismos do esquecimento. Mesmo próximos eles viram logo passado remoto. Surgem às vezes, na lembrança, como se fossem uma incongruência. Só aparentemente sem razão porque não há associação de ideias que seja ilógica. O que assim parece, em verdade, liga-se e harmoniza-se no subconsciente pelas raízes subterrâneas - raízes lógicas! - de que emergem os pequenos caules isolados - aparentemente ilógicos! só aparentemente! Às vezes chegados à memória, vindos do esquecimento que é outra função ativa dessa mesma memória. Sobem como pés de tiririca, emergem como Açores e Madeiras, ilhas perdidas na superfície oceânica, entretanto pertencentes a um sistema entrosado de montanhas subatlânticas. (NAVA, 1974, p, 233).

Perfume de sumo de laranja no frio ácido das noites de junho. Escalas de piano ouvidas ao sol desolado das ruas desertas. Umas imagens puxam as outras e cada sucesso entregue assim devolve tempo e espaço comprimidos e expande, em quem evoca essas dimensões, revivescências povoadas do esquecido pronto para renascer. Porque esquecer é fenômeno ativo e intencional - esquecer é capítulo da memória (assim como que o seu tombo) e não sua função antagônica. Na recordação voluntária não podemos forçar a mecânica com que as lembranças nos são dosadas. Os fatos sumidos nos repentes, em vez de todos, em cadeia, voltam de um em um. Às vezes, um só. Esse se oferece para suprir e vicariar os que as defesas do psiquismo acham que não é hora de dar e ele é uma espécie de "em vez de" acontecimento, imagem que tem de ser coagida pelo consciente, para soltar outros, outros e nos dar aparência do integral não achado, mas construído (tiririca, de que é preciso forçar o minúsculo pé, para fazer sair da terra os metros de raízes ocultas que ligavam moitas emergentes e distantes). (NAVA, 1974, p. 304, grifo do autor).

O modelo proposto por Nava para o "esquecimento" é um dinâmico "sistema entrosado de montanhas subatlânticas", onde imagens se atraem, se movem, "puxam as outras", libertam do oblívio as dimensões comprimidas do tempo e espaço, expandindo por meio de cada evocação "revivescências povoadas do esquecido pronto para renascer". Engrenagem desse "fenômeno ativo e intencional", esquecer não é função antagônica da memória, e sim profilática, conforme "as defesas do psiquismo". A disposição de fatos e imagens, "coagida pelo consciente", resulta num constructo mnemônico final “(tiririca, de que é preciso forçar o minúsculo pé, para fazer sair da terra os metros de raízes ocultas 
que ligavam moitas emergentes e distantes)". O arranjo desse agrupamento complexo de funções comunicantes, difusas e heterogêneas para as ações de lembrar e esquecer seria análogo ao conceito de rizoma apresentado pelos filósofos Gilles Deleuze e Félix Guattari (1995).

A noção de rizoma em questão provém da biologia, porém diverge do padrão hierárquico em que um eixo central verticalizado subdivide-se em ramificações sucessivas, feito a imagem da árvore brônquica ou da árvore genealógica. De acordo com a perspectiva de Deleuze e Guattari (1995, p. 1516), o rizoma percorre conexões heterogêneas, "efetuando um descentramento sobre outras dimensões e outros registros", segundo leis de combinação interativas que lhe atribuem multiplicidade. O Uno faz parte do múltiplo sempre subtraído dele, estado que poderia ser designado pela expressão "n-1":

Subtrair o único da multiplicidade a ser constituída; escrever a n-1. Um tal sistema poderia ser chamado de rizoma. Um rizoma como haste subterrânea distingue-se absolutamente das raízes e radículas. Os bulbos, os tubérculos, são rizomas. Plantas com raiz ou radícula podem ser rizomórficas num outro sentido inteiramente diferente: é uma questão de saber se a botânica, em sua especificidade, não seria inteiramente rizomórfica. [...] O rizoma nele mesmo tem formas muito diversas, desde sua extensão superficial ramificada em todos os sentidos até suas concreções em bulbos e tubérculos. [...] Há o melhor e o pior no rizoma: a batata e a grama, a erva daninha. (DELEUZE, GUATTARI, 1995, p. 15).

Para Deleuze e Guattari, o rizoma é um sistema autorreferencial que se expande destituído de um centro, com linhas de fuga que revelam diferentes alternativas ou padrões de organização. O Uno não é um apêndice desse conjunto múltiplo orientado pelos princípios da conexão e mutabilidade. No modelo estabelecido por Nava (1974, p. 304) sobre o esquecimento, o Uno é configura no evento que se desprende de um ponto onde estava cristalizado, "adormecido", e flutua através dos planos ou do "Bosque do inconsciente" para assumir outras relações com a imaginação e a consciência vígil: "[...] fatos sumidos nos repentes, em vez de todos, em cadeia, voltam de um em um. Às vezes, um só. [...] acontecimento, imagem que tem de ser coagida pelo consciente, para soltar outros, outros e nos dar aparência do integral [...] os metros de raízes ocultas que ligavam moitas emergentes e distantes". O padrão fluido e não estratificado do rizoma é ilustrado por uma reflexão de Henry Miller que se aplicaria, igualmente, à metáfora de Nava sobre o "esquecer" na qualidade de capítulo da memória:

A erva daninha é a Nêmesis dos esforços humanos. Entre todas as existências imaginárias que atribuímos às plantas [...] é talvez a erva daninha aquela que leva a vida mais sábia. [...] A erva existe exclusivamente entre os grandes espaços não cultivados. Ela preenche os vazios. Ela cresce entre e no meio das outras coisas. (MILLER apud DELEUZE, GUATTARY, 1995, p. 29-30, grifo do autor)

A metáfora do rizoma com suas linhas de fuga aplica-se igualmente à estrutura composicional das Memórias, em que diferentes estilos de narrar entrelaçam passagens autobiográficas, biográficas, digressivas, ensaísticas e líricas. O esforço de "atar as duas pontas da vida", de preencher os "vazios" da narrativa (auto)biográfica é compensado pela memória associativa ou memória involuntária:

[...] quando fico triste, triste [...], só quero reencontrar o menino que já fui. Assim, quantas e quantas vezes viajei, primeiro no espaço, depois no tempo, em minha busca, na de minha rua, na de meu sobrado [...] não havia meios da recordação provocada entregar-me a velha imagem. Foi preciso o milagre da memória involuntária [...] como aquele raio que alumbrou São Paulo e fê-lo desabar na Estrada de Damasco. [...] tudo, tudo, todos, todos se reencarnando num presente repentino, outra vez palpável, visível, magmático, coeso, espesso e concentrado - tal a súbita franja feita por limalha de ferro atraída pela força dum imã. (NAVA, 1974, p. 301-302). 
O modelo mnemônico de Nava, análogo à disposição pluralizante do rizoma, mostra-se ora difuso, na rede tecida pela memória associativa, ora "coeso" pelo "milagre da memória involuntária". Outro aspecto que aproxima o sistema naveano do proposto por Deleuze e Guattari alude à fronteira entre ficção e realidade. Esta pode se alterar ou desvanecer na tentativa de recuperação do passado, como sugere o narrador de Dom Casmurro: “[...] relembrar as nossas tristezas e calamidades, mas isso mesmo era um modo de não sairmos de nós” (ASSIS, 1978, p. 302). Na transcrição do passado,

Há assim uma memória involuntária que é total e simultânea. Para recuperar o que ela dá, basta ter passado, sentindo a vida; basta ter, como dizia Machado, "padecido no tempo". A recordação provocada é antes gradual, construída, pode vir na sua verdade ou falsificada pelas substituições cominadas, pela nossa censura. (NAVA, 1974, p. 306).

As substituições cominadas pela censura, por uma "esmagadora oportunidade poética" ou em razão de questões éticas são linhas de fuga que acrescentam às Memórias uma dimensão ficcional. A origem de uma recordação, segundo a configuração do rizoma, não é determinada por vias unívocas: “[...] os rizomas têm também seu próprio despotismo, sua própria hierarquia" (DELEUZE; GUATTARI, 1995, p. 31). A memória associativa desempenha um papel criativo na escrita literária na exploração das nuances que muitas vezes escapam à lógica da consciência vígil. Nessa acepção, alguns relatos das Memórias formam um tipo de rizoma, cujos espaços entre a digressão e a narrativa são preenchidos pela crença, experiência, imaginação, repertório de leituras ou perspectiva do leitor:

Que engano tomar os fantasmas como ilusões dos sentidos abusados por formas indistintas... São os duendes mesmo e as aparições que, quando espantadas com o pelo-sinal e o nome da Virgem, se escondem rapidamente nas roupas penduradas no escuro, nas largas folhas brilhando ao luar ou no lampejo das águas dormentes. (NAVA, 1974, p. 105).

A técnica narrativa é também rizomática quando recupera estórias e histórias do passado, explorando e tornando únicos motivos, temas, os mortos e seus casos, retratos, testemunhos: "Assim a anarquia infantil do Tempo e do Espaço me impedem de contar Juiz de Fora em ordem certa, capítulo um, capítulo dois, capítulo três. São mil capítulos e inumeráveis - entretanto capítulo único". Convém ressaltar um último ponto de contato entre o modelo de rizoma e a estrutura das Memórias, investigar a riqueza de sua composição atrairia inevitavelmente uma abordagem interdisciplinar. 


\section{Referências}

ASSIS, Machado. Dom Casmurro. São Paulo: Abril Cultural, 1978.

BARBOUR, John D. Judgind and Not Judging Parents. In: EAKIN, Paul John (Ed.). The Ethics of Life Writing. Ithaca and London: Cornel University Press, 2004. p. 73-100.

DELEUZE, Gilles; GUATARRI, Félix. Introdução: Rizoma. In: Mil Platôs: capitalismo e esquizofrenia. Tradução de Aurélio Guerra e Célia Pinto Costa. Rio de Janeiro: Editora 34, 1995. V. 1. p. 11-37.

NAVA, Pedro. Baú de ossos. Rio de Janeiro: Livraria José Olympio, 1974.

ARSÊNIO NETTO, Firmino de. As crises de um ideal: os primórdios do Instituto Granbery, 18891922. Piracicaba: Editora Unimep. 1997.

MACWHINEY, Brian. The Emergence of Grammar from Perspective. In: PECHER, Diane; ZWAAN, Rolf A (Eds.). Grounding Cognition: The Role of Perception and Action in Memory, Language, and Thinking. Cambridge: Cambridge University Press, 2005. p. 198-224.

RICOEUR, Paul. La Mémoire, L'Histoire, L'Oubli. Paris: Editions du seil, 2000.

RÓNAI, Paulo. As estórias de Tutameia. In: ROSA, João Guimarães. Aletria e Hermenêutica. In: Tutameia: Terceiras Estórias. Rio de Janeiro: Nova Fronteira, 2009. p. 20-23.

ROSA, João Guimarães. Antiperipleia. In: Tutameia: Terceiras Estórias. Rio de Janeiro: Nova Fronteira, 2009, p. 31-34; 53-55. 